\title{
VYJADRENIE ZÁVISLEJ PRÁCE V POISŤOVACOM SYSTÉME SR
}

\author{
MILOŠ LACKO*
}

\begin{abstract}
Expression of dependent work in Insurance System of the Slovak Republic
The current period is characterized by an increase in the performance of dependent work its new forms supported by the information technology. These new forms, due to guaranteeing the social protection, require a change of approach both in the area of labour law and in the field of social protection systems based on the insurance policy. The Slovak legislator undertook extensive changes in the insurance system between the years of 2011 and 2013, linking the definition of the insurance category of employee to the tax classification of income from the employment. The contribution focuses on and evaluates the impact of this change on the expanding group of protected persons exercising employment in selected types of legal relationships, and in particular for persons carrying out activities on the basis of agreements on work performed outside the employment relationship, including status exceptions (i.e. beneficiaries of basic pension benefits and pupils / students performing temporary occasional or seasonal work) and managers (and associates) of limited liability companies. The contribution also shows the lack of readiness and systemic consistency of the legislation regulating the coexistence of the employment and the entitlement to the payment of certain benefits from the social insurance system (maternity benefit and early old-age pension).
\end{abstract}

Keywords: the insurance category of employee; insurance dimension of the agreements to work outside the scope of employment relationship; levy participation of managers (and associates) of limited liability companies; the impact of dependent work performance on the payment of certain benefits from the social insurance system

Kl’účové slová: poistná kategória zamestnanca; poistný rozmer dohôd o prácach vykonávaných mimo pracovného pomeru; odvodová participácia konatel’ov (aj spoločníkov) spoločností s ručením obmedzením; vplyv výkonu závislej práce na výplatu niektorých dávok sociálneho poistenia

DOI: $10.14712 / 23366478.2019 .4$

\footnotetext{
* Autor je tajomníkom a členom katedry pracovného práva a práva sociálneho zabezpečenia na Právnickej fakulte Trnavské univerzity v Trnave. Príspevok spracoval s finančnou podporou projektu Agentúry na podporu výskumu a vývoja č. APVV-15-0066 pod názvom „Nové technológie v pracovnom práve a ochrana zamestnanca“. Zodpovedná riešitel'ka prof. JUDr. Helena Barancová, DrSc., PF Trnavskej univerzity v Trnave.
} 


\section{ÚVOD}

Systémy sociálnej ochrany (možno použit' aj označenie sociálnej bezpečnosti), ktoré pre svoju existenciu a plnenie stanovených sociálnych úloh vyžadujú aktívnu participáciu, sú v dôsledku tohto systémového (výstavbového) prvku spravidla vybudované na aktívnej príspevkovej (odvodovej) participácii osôb (účastníkov systému), ktorú odvodzujú od príjmov plynúcich z výkonu zárobkovej činnosti realizovanej v predvídaných formách. Základnými formami výkonu zárobkovej činnosti v príspevkových systémoch sociálnej ochrany sú výkon závislej činnosti a výkon samostatnej zárobkovej činnosti.

Následne výkon závislej práce je uskutočňovaný vo viacerých variáciách pod jednotiacim základom pojmového vymedzenia „klasického“ zamestnanca vykonávajúceho závislú prácu, pričom podla pracovnoprávnej teórie nespochybnitel'nými prvkami pojmu zamestnanec sú osobný výkon práce a subordinačný princíp ${ }^{1}$. Tieto pojmové znaky zamestnanca sú $v$ podstatnej miere determinované práve charakterom vykonávanej (závislej) práce. Podla § 1 Zákonníka práce závislou prácou, ,je práca vykonávaná vo vztahu nadriadenosti zamestnávatel'a a podriadenosti zamestnanca, osobne zamestnancom pre zamestnávatel'a, podl'a pokynov zamestnávatel'a, v jeho mene, v pracovnom čase určenom zamestnávatel'om“. V nasledujúcom odseku uvedeného ustanovenia Zákonníka práce je vyjadrený zákaz výkonu závislej práce v zmluvnom občianskoprávnom vzt’ahu alebo v zmluvnom obchodnoprávnom vzt’ahu.

Je len preferenčnou vol'bou zákonodarcu zohl'adňujúcou a rešpektujúcou ochrannú funkciu sociálneho zabezpečenia, ktorým skupinám zamestnancov definovaných selektívnymi znakmi poskytne a zaručí určitý stupeň hmotného zabezpečenia (resp. sociálnej ochrany), a to jednak čo do rozsahu krytých sociálnych udalostí a jednak čo do úrovne poskytovaného hmotného zabezpečenia kvantifikovaného prizmou hodnôt sociálnej potrebnosti a adekvátnosti (resp. primeranosti). V poslednom období je podstata zaužívaných schém a prístup $\mathrm{k}$ tvorbe úrovne poskytovaného hmotného zabezpečenia fyzických osôb vykonávajúcich závislú prácu v pracovnom pomere a obdobnom pracovnom vzt’ahu ohrozovaná jednak únikom do oblasti výkonu podnikatel'skej činnosti prostredníctvom obchodných spoločností a jednak vznikom nových digitálnych platforiem výkonu zárobkovej činnosti oslabujúcich subordinačný princíp výkonu závislej práce (napr. tzv. „uberizácia“²).

1 K analýze pojmových znakov zamestnanca a $\mathrm{k}$ novodobým špecifikám výkonu závislej práce pozri BARANCOVÁ, H. Teoretické problémy pracovného práva. Plzeň: Aleš Čeněk, 2013. s. 74-83. ISBN 978-80-7380-465-7.

2 K postaveniu vodiča služby Uber ako kvázi zamestnanca v modeloch kolaboratívnej ekonomiky pozri BARANCOVÁ, H. Zamestnanec, štatutár a spoločník v pracovnom práve. Praha: Leges, 2018. s. 75 a nasl. ISBN 978-80-7502-300-1.

K argumentácí založenej na skutkových okolnostiach prejedávaných sporov, či vodič Uberu je kvázi zamestnancom alebo nezávislým podnikatel’om pozri KRIŽAN, V. Uber v rozhodovacej činnosti orgánov práva. In: BARANCOVÁ, H. - OLŠOVSKÁ, A. (eds.). Pracovné právo v digitálnej dobe. Praha: Leges, 2017, s. 121-124. ISBN 978-80-7502-259-2. 
Uvedené v konečnom dôsledku destabilizujúco pôsobí na finančnú udržatel'nost' príspevkových systémov sociálnej ochrany, ak sú vybudované na samofinancovaní (t. j. odpojení od iných rozpočtových sústav) a osobitne počas obdobia ekonomickej recesie.

Slovenský zákonodarca vykonal v právnej úprave poist'ovacieho systému SR (pozostáva zo systému sociálneho poistenia a systému verejného zdravotného poistenia) niekol'ko krokov, ktorými čiastočne reaguje na výkon závislej práce, čím predovšetkým sleduje zaistenie finančnej udržatel'nosti poistných systémov vytvárajúcich poist'ovací systém $\mathrm{SR}^{3}$. V nasledujúcich častiach príspevku priblížime uvedené kroky slovenského zákonodarcu a poukážeme na niektoré zjavné kontroverzie vyvolané jeho legislatívnymi krokmi, ktoré súčasne znižujú (resp. ohrozujú) úroveň sociálnej ochrany.

\section{ZMENA VO VYMEDZENÍ POISTNEJ KATEGÓRIE ZAMESTNANCA}

V právnej úprave poistných systémov Slovenskej republiky 4 do 31 . decembra 2010 dominoval enumeratívny prístup vo vymedzení skupín fyzických osôb vykonávajúcich závislú prácu v pracovnom pomere alebo obdobnom pracovnoprávnom vzt'ahu (dodávame, že obdobný prístup sa uplatňoval aj u poistnej kategórie samostatne zárobkovo činnej osoby 5 ). Podl'a ustanovenia 33 zákona č. 461/2003 Z. z. o sociálnom poistení účinného do 31 . decembra 2010 sa zárobkovou činnostou na účely nemocenského poistenia, dôchodkového poistenia a poistenia v nezamestnanosti rozumela primárne činnost' zamestnanca $\mathrm{v}$ pracovnom pomere, pričom na jeho roveň boli postavené fyzické osoby v štátnozamestnaneckom pomere, v služobnom pomere, v pracovnom vzt'ahu k družstvu, v postavení ústavného činitel’a, verejného ochrancu práv, v postavení predsedu vyššieho územného celku, poslanca vyššieho územného celku, starostu a primátora, riaditel’a štátneho podniku a napokon osôb vo výkone trestu odňatia alebo vo výkone väzby, ak boli zaradené na výkon prospešných prác (mimo ústavu).

Na účely zdravotného poistenia sa do 31 . decembra 2010 považovala za zamestnanca, okrem už uvedených skupín fyzických osôb v systéme sociálneho poistenia, aj fyzická osoba $\mathrm{v}$ postavení:

- konatel'a spoločnosti s ručením obmedzeným, ak za túto prácu dostával odmenu považovanú za príjem zo závislej činnosti podl’a zákona č. 595/2003 Z. z. o dani z príjmov,

- člena štatutárneho orgánu, člena správnej rady, člena dozornej rady, člena kontrolnej komisie a člena iného samosprávneho orgánu právnickej osoby, ak za výkon

3 Poznamenávame, že systém sociálneho poistenia pozostáva z nemocenského poistenia, dôchodkového poistenia, poistenia $\mathrm{v}$ nezamestnanosti a úrazového poistenia a garančného poistenia, pričom posledne dva uvedené poistné systémy sú poistením zamestnávatel'a.

4 Poist'ovací systém SR pozostáva z dvoch samostatných poistných systémov, a to systému sociálneho poistenia upraveného zákonom č. 461/2003 Z. z. a systému verejného zdravotného poistenia upraveného zákonom č. 580/2004 Z. z.

5 Pre komplexnost’ informácie uvádzame, že tret’ou poistnou kategóriou v systéme sociálneho poistenia je dobrovol'ne poistená osoba a v systéme verejného zdravotného poistenia je to okrem zamestnanca a samostatne zárobkovo činnej osoby samoplatitel’ poistného (definovaný v § 11 ods. 2 zákona č. 580/2004 Z. z.) 
funkcie dostával odmenu považovanú za príjem zo závislej činnosti podl’a zákona č. 595/2003 Z. z.,

- spoločníka spoločnosti s ručením obmedzeným, komanditistu komanditnej spoločnosti, ak boli odmeňovaní za prácu $\mathrm{v}$ spoločnosti formou, ktorá sa podla zákona č. 595/2003 Z. z. považovala za príjem zo závislej činnosti.

Uvedené nazeranie na poistnú kategóriu zamestnanca zákonodarca zásadne extenzívne redefinoval previazaním na daňovú klasifikáciu príjmov zo závislej činnosti (zákonom č. 543/2010 Z. z. meniacim zákon sociálnom poistení a zákonom č. 499/2010 Z. z. meniacim zákon o zdravotnom poistení s účinnostou od januára 2011), ked’že právna úprava daňovo klasifikovaných príjmov zo závislej činnosti je v zásade založená na subordinačnom znaku pracovnoprávneho vzt’ahu ,dodržiavania alebo plnenia príkazov/ pokynov ukladaných platitel'om príjmu alebo inou osobou" identifikovaného v širšom spektre právnych vzt’ahov, a v prípade niektorých právnych vzt'ahov ale značne oslabeného, čo je len dôsledkom charakteru a účelu daného právneho vzt’ahu z ktorého plynie daňovníkovi príjem a ktorý zákonodarca cielene hodnotí ako príjem zo závislej činnosti. Takým príkladom sú platy a funkčné príplatky ústavných činitel'ov Slovenskej republiky, verejného ochrancu práv, poslancov Európskeho parlamentu zvolených na území SR, ktorí vykonávajú svoj mandát osobne podl’a svojho svedomia a presvedčenia a nie sú viazaní príkazmi (čl. 73 ods. 2 Ústavy SR) a v prípade verejnej funkcie nestranne a dodržiavajúc a uplatňujúc právny poriadok SR a osobitne chrániac verejný záujem a základné ludské práva a slobody.

Zárobkovou činnost’ou sa na účely sociálneho poistenia a (verejného) zdravotného poistenia rozumie príjem, ktorý je podla zákona č. 595/2003 Z. z. klasifikovaný ako zdanitel'ný príjem zo závislej činnosti ${ }^{6}$ okrem nepeňažného príjmu z predchádzajúceho právneho vzt’ahu, ktorý zakladal právo na príjem zo závislej činnosti poskytnutého z prostriedkov sociálneho fondu. Ďalej sa zárobkovou činnost'ou (zamestnanca) rozumie aj činnost', z ktorej príjem nepodlieha dani z príjmov v dôsledku dodržania zákazu dvojitého zdanenia. Napokon zárobkovou činnost’ou je činnost' fyzickej osoby, z ktorej príjem zo závislej činnosti nepodlieha dani z príjmov, ale na túto fyzickú osobu sa

6 Najvýznamnejšími zdanitel’nými príjmami zo závislej činnosti sú:

a) príjmy zo súčasného alebo z predchádzajúceho pracovnoprávneho vzt'ahu, služobného pomeru, štátnozamestnaneckého pomeru alebo členského pomeru, alebo z obdobného vzt’ahu, v ktorom je daňovník povinný dodržiavat' pokyny alebo príkazy platitel’a príjmu,

b) príjmy za prácu likvidátorov, prokuristov, nútených správcov, členov družstiev, spoločníkov a konatelov spoločností s r. o. a komanditistov k. s., a to aj ked’ nie sú povinní pri výkone práce pre družstvo alebo pre spoločnost' dodržiavat' príkazy inej osoby,

c) platy a funkčné príplatky ústavných činitel’ov, verejného ochrancu práv, poslancov EP, prokurátorov a vedúcich ostatných ústredných orgánov štátnej správy SR,

d) odmeny za výkon funkcie $\mathrm{v}$ štátnych orgánoch, $\mathrm{v}$ orgánoch územnej samosprávy a $\mathrm{v}$ orgánoch iných právnických osôb alebo spoločenstiev,

e) odmeny obvinených vo väzbe a odmeny odsúdených,

f) príjmy z prostriedkov sociálneho fondu,

g) príjmy plynúce v súvislosti s minulým, súčasným alebo budúcim výkonom závislej činnosti alebo funkcie bez ohl'adu na to, či daňovník pre platitel’a príjmu skutočne vykonával, vykonáva alebo bude vykonávat' túto závislú činnost' alebo funkciu,

h) príjmy z činnosti športovca na základe zmluvy o profesionálnom vykonávaní športu a príjmy z činnosti športového odborníka na základe zmluvy o výkone činnosti športového odborníka (od roku 2019). 
uplatňujú sociálnozabezpečovacie právne vzt’ahy SR podl’a koordinačných pravidiel obsiahnutých v nariadení Európskeho parlamentu a Rady (ES) č. 883/2004 z 29. apríla 2004 o koordinácii systémov sociálneho zabezpečenia ${ }^{7}$ alebo podl’a medzinárodnej zmluvy, ktorá má prednost' pred zákonmi SR. Naopak zárobkovou činnost’ou nie je činnost' vykonávaná v právnom vzt’ahu, z ktorej plynúce príjmy nie sú predmetom dane alebo sú od dane oslobodené.

Zárobkovou činnost'ou na účely systému zdravotného poistenia nie je ani činnost', na základe ktorej plynú príjmy, z ktorých sa daň vyberá zrážkou, a ani príjem, ktorý predstavuje odchodné, výsluhový príspevok alebo je rekreačnou starostlivost'ou poskytovanou zo systému sociálneho zabezpečenia policajtov a vojakov podla zákona č. 328/2002 Z. z. o sociálnom zabezpečení policajtov a vojakov. Dodávame, že na účely platenia poistného na verejné zdravotné poistenie zákonodarca zahrnul do vymeriavacieho základu na platenie poistného (aplikujúceho sa na účely ročného zúčtovania preddavkov na poistné na zdravotné poistenie) aj daňovo klasifikované príjmy z kapitálového majetku a tzv. ostatné príjmy ${ }^{8}$.

Daňovo-právny prístup ku kvalifikácii určitej činnosti ako výkonu závislej práce možno stručne uviest' na pozadí rozhodovacej činnosti Najvyššieho súdu $\mathrm{SR}^{9}$, podl'a ktorého klúčovým kritériom je posúdenie prejavu vôle („byt'“ zamestnancom alebo podnikatel'om), t. j. rozdiel nie je identifikovatel'ný v obsahu právneho úkonu (resp. právneho vzt’ahu ${ }^{10}$ ale v subjekte, ktorý prejavuje vôl'u smerujúcu k uzatvoreniu určitého právneho úkonu. Takto nastavený judikatórny prístup ale nedáva odpoved’ na riešenie problematiky zastretých pracovnoprávnych vzt’ahov nepomenovanými zmluvami označovaných aj ako tzv. „Švarc systém“ čo má v konečnom dôsledku nepriaznivé dôsledky na samotné zdrojové financovanie príspevkových (poistných) systémov sociálnej ochrany.

V porovnaní s právnym stavom účinným do 31 . decembra 2010 sa značne rozšírilo definičné vymedzenie poistnej kategórie zamestnanca, ktorým je fyzická osoba vykonávajúca zárobkovú činnost’ v právnom vzt’ahu, ktorý jej zakladá právo na „zdanitel'ný“ príjem zo závislej činnosti (prvý definičný znak), pričom tento príjem môže byt' $\mathrm{v}$ rámci daného právneho vzt’ahu poskytovaný pravidelne mesačne alebo nepravidelne. Periodicita vzniku práva na poskytnutie príjmu zo závislej činnosti, ako druhý definičný

7 Ú. v. EÚ, L 284, dňa 30. 10. 2009.

8 Poznamenávame, že poistné na zdravotné poistenie sa platí aj z podielu na zisku (dividend), ak boli vyplatené fyzickej osobe podiel'ajúcej sa na základnom imaní obchodnej spoločnosti alebo družstva zo zisku z účtovného (resp. zdaňovacieho) obdobia 2011 až 2016. Od roku 2017 je dividenda zdaňovaná 7 \% zrážkovou daňou. V rámci sociálneho poistenia platí poistné na nemocenské poistenie, dôchodkové poistenie a poistenie $\mathrm{v}$ nezamestnanosti zamestnanec aj podielu na zisku vyplateného obchodnou spoločnost'ou alebo družstvom, ak sa majetkovo nepodiel'a na ich základnom imaní.

9 Rozsudok NS SR sp. zn. 3 Sžf 80/2008 zo dňa 23. apríla 2009. Dostupné online na: <http://merit.slv .cz/3Szf80/2008>, navštívené dňa 29. októbra 2018.

10 Odporca $\mathrm{v}$ danej veci prekvalifikoval príjmy z podnikania na príjmy zo závislej činnosti s právnym poukazom na znenie $\S 2$ ods. 3 a 6 zákona č. 511/1992 Zb. (v súčasnosti § 3 a 6 zákon č. 563/2009 Z. z. o správe daní (daňový poriadok) a o zmene a doplnení niektorých zákonov), a to najmä že ,pri uplatňovaní daňových predpisov v daňovom konaní sa berie do úvahy vždy skutočný obsah právneho úkonu alebo inej skutočnosti rozhodujúcej pre určenie alebo vybratie dane.“ 
znak poistnej kategórie zamestnanca, má zásadný dopad na rozsah obligatórnej participácie v systéme sociálneho poistenia.

Do súčasného právneho znenia zaznamenala poistná kategória dve významné modifikácie, a to zákonom č. 252/2012 Z. z. a krátko na to zákonom č. 413/2012 Z. z., ktoré priniesli jej rozšírenie o fyzické osoby v právnom vzt’ahu na základe dohôd o prácach vykonávaných mimo pracovného pomeru s nižšie uvedenými viacerými výnimkami, pričom jej aktuálnu „expandovanú“ podobu finalizoval zákon č. 266/2017 Z. z. účinný od 1. júla $2018^{11}$.

Ak daný právny vzt’ah zakladá právo na pravidelný mesačný príjem zo závislej činnosti, tak je fyzická osoba v plnom rozsahu zapojená do podsystémov sociálneho poistenia, t. j. je povinne nemocensky, dôchodkovo poistená a poistená v nezamestnanosti. Teda rozsah sociálnej ochrany zamestnanca je štandardný a touto redefiníciou poistnej kategórie sa v dôsledku daňovej kvalifikácie právneho vztahu, v ktorom sa vykonáva závislá pracovná činnost' iba rozšíril na väčší rozsah právnych vzt’ahov (napr. o právne vzt'ahy, v ktorých sa uskutočňujú kompetencie likvidátorov, prokuristov, nútených správcov, členov družstiev, spoločníkov a konatel'ov spoločností s ručením obmedzeným). Osobitne sú od 1 . januára 2013 zahrnuté aj fyzické osoby vykonávajúce prácu v právnom vzt’ahu na základe jednej z dohôd o prácach vykonávaných mimo pracovného pomeru s nižšie uvedenými oslobodzovacími odvodovými výnimkami.

Ak vyššie naznačený právny vzt’ah zakladá právo na nepravidelný mesačný príjem zo závislej činnosti, tak je fyzická osoba povinne zapojená len a výlučne do jedného podsystému sociálneho poistenia, a to dôchodkového poistenia. Dokonca ak splní statusovú podmienku, ktorá je spravidla spojená s podmienkou príjmového testu, tak je vylúčená aj z účasti na dôchodkovom poistení.

Bez ohl'adu na pravidelnost' príjmu zo závislej činnosti dosahovaného na základe dohody o pracovnej činnosti alebo dohody o vykonaní práce sú výlučne povinne dôchodkovo poistené fyzické osoby v postavení poberatel'a:

1. starobného dôchodku,

2. predčasného starobného dôchodku,

3. invalidného dôchodku, resp. invalidného výsluhového dôchodku,

4. výsluhového dôchodku, ak dovŕšili dôchodkový vek a

súčasne, ak ich mesačný príjem $\mathrm{v}$ podobe odmeny alebo priemernej mesačnej odmeny $z$ danej dohody presiahne $200 €$. Ak táto odmena u týchto statusovo definovaných fyzických osôb (poberatel'ov dôchodkových dávok) nepresiahne $200 €$, tak sú úplne vylúčení z účasti na podsystémoch sociálneho poistenia. Podotýkame, že uvedené príjmové vylúčenie sa vzt’ahuje len na jednu dohodárom (zamestnancom) určenú dohodu o prácach vykonávaných mimo pracovného pomeru (§ 227a ZoSP) a pre statusovú skupinu poberatel'a predčasného starobného dôchodku ${ }^{12}$ bolo zavedené zákonom č. 266/2017 Z. z. účinným od júla 2018.

11 Bližšie pozri: https://www.socpoist.sk/dohodari-a-postup-voci-sp-od-1-jula-2018/66096s, navštívené dňa 8. októbra 2018.

12 Poberatel' predčasného starobného dôchodku do uvedeného dátumu nemohol vykonávat' zárobkovú činnost' (zakladajúcu povinné dôchodkov poistenie) bez právneho následku zániku nároku na výplatu tohto dôchodku. Toto pravidlo sa ale už neaplikuje na situáciu ak tento poberatel' dôchodku dovíši dôchodkový 
Oproti uvedeným statusovým skupinám status študenta dennej formy vysokoškolského štúdia a žiaka strednej školy vykonávajúceho zárobkovú činnost' na základe dohody o brigádnickej práci študenta bol zavedený od začiatku tejto osobitnej právnej úpravy, t. j. od roku 2013. Táto právna úprava bola iba raz zásadne zmenená v prospech väčšieho vylúčenia týchto dvoch statusových podskupín z podsystému dôchodkového poistenia, a to zvýšením príjmovej hranice vylučujúcej vznik a existenciu povinného dôchodkového poistenia vrátane plnenia oznamovacej povinnosti zamestnávatel'a a riešenia situácie dodatočne vyplateného príjmu po skončení právneho vzt’ahu založeného dohodou o brigádnickej práci študenta (v súčasnosti to platí už na všetky dohody o prácach vykonávaných mimo pracovného pomeru).

Vzhl'adom na doteraz uvedené, bez ohl'adu na pravidelnost' príjmu zo závislej činnosti dosahovaného na základe dohody o brigádnickej práci študenta sú výlučne povinne dôchodkovo poistené fyzické osoby v postavení:

1. žiaka strednej školy do 18 . roku veku, ak (priemerný) mesačný príjem z tejto dohody (u jedného zamestnávatel'a) presiahne $200 €$ (predtým $66 €$ ),

2. študenta dennej formy vysokoškolského štúdia najdlhšie do 26 . roku veku' ${ }^{13}$, ak (priemerný) mesačný príjem z tejto dohody (u jedného zamestnávatel’a) presiahne $200 €($ predtým $155 €)$.

Uvedená príjmová hranica sa aplikuje aj na žiaka strednej školy a študenta vysokej školy pri praktickom vyučovaní v rámci odbornej (výrobnej) praxe, ktorý dosahuje $\mathrm{v}$ rámci tejto výučby a praxe (priemerný) mesačný príjem.

Ako bolo vyššie naznačené, tak vylúčenie (oslobodenie) z účasti na podsystémoch sociálneho poistenia sa vzt'ahuje len na jednu dohodárom (či poberatel'om vyššie uvedenej dôchodkovej dávky alebo žiakom / študentom) určenú dohodu, ak ich dohodár v danom mesiaci má uzatvorených viac a v tomto prípade bez ohl'adu na výšku príjmu, „dohodár“ prostredníctvom zakotveného práva vol’by (v § 227a zákona o sociálnom poistení) určí u svojho zamestnávatel’a čestným vyhlásením (vzor je zverejnený na portáli Sociálnej poistovne) iba jednu dohodu, na základe ktorej nebude mat' postavenie zamestnanca na účely dôchodkového poistenia ${ }^{14}$. Právne účinky uplatnenia tohto práva nastanú odo dňa vzniku právneho vzt’ahu založeného danou dohodou za predpokladu, že uplatnenie práva bolo zamestnávatel’ovi oznámené najneskôr $\mathrm{v}$ deň vzniku právneho vzt’ahu; inak od prvého dňa nasledujúceho kalendárneho mesiaca, v ktorom dohodár uskutočnil oznámenie zamestnávatel'ovi o uplatnení uvedeného práva. A právne účinky ukončenia uplatnenia práva dohodárom nastanú od prvého dňa nasledujúceho kalendárneho mesiaca, v ktorom bolo ukončenie uplatnenia práva oznámené zamestnávatel'ovi.

$\mathrm{V}$ prípade uvedených dvoch statusových kategórií dohodárov a ich práva na nepravidelnú odmenu (počas trvania danej dohody o prácach vykonávaných mimo pracovného pomeru) vo vzt’ahu k naplneniu podmienky príjmového testu oslobodzujúceho

vek. Od tohto okamihu zákonodarca zakotvuje žiadne pravidlo vylučujúce súbeh výkonu zárobkovej činnosti a poberania dôchodkovej dávky ( $\mathrm{v}$ tomto prípade starobného dôchodku).

13 Uvedené dve statusové požiadavky (vekové ohraničenie a forma vysokoškolského štúdia) na osobu v postavení zamestnanca na základe dohody o brigádnickej práci študentov zaviedla novela zákonníka práce s účinnost’ou od 1. januára 2013, t. j. zákon č. 252/2012 Z. z.

$14 \mathrm{~K}$ tomu bližšie pozri: <https://www.socpoist.sk/zamestnanec-dohodar/55424s\#03>, navštívené dňa 30. októbra 2018. 
ich z povinnej participácie na dôchodkovo poistení sa musí teória práva sociálneho zabezpečenia vysporiadat's novou materiálnou okolnost'ou, ktorá vyvolala požiadavku dodatočnej a spätnej registrácie už skončeného poistného vzt’ahu, ktorý v reálnom čase trvania danej dohody o prácach vykonávaných mimo pracovný pomer neexistoval. Tento právny stav odôvodňuje skutočnost', že v prípade dohodára s nepravidelným odmeňovaním $\mathrm{v}$ jednej $\mathrm{z}$ vyššie uvedených statusových pozícii nemožno pred a $\mathrm{v}$ čase trvania danej dohody porovnat výšku odmeny s príjmovou hranicou oslobodzujúcou od povinnej participácie na dôchodkovom poistení ${ }^{15}$.

Ďalej uvádzame osobitnú, i ked’ nie výnimočnú situáciu, ked’ dohodár má uzatvorenú jednu dohodu o prácach vykonávaných mimo pracovného pomeru s príjmom vy̌̌ším ako je vyššie uvedená $200 €$ hranica a uplatní si vol'bou práva vylúčenie z odvodovej povinnosti, tak mu vznikne povinné dôchodkové poistenie s povinnost'ou platit' poistné na dôchodkové poistenie ( $v$ členení na starobné poistenie $(4 \%)$ a invalidné poistenie $\left.(3 \%)^{16}\right)$ iba zo sumy prevyšujúcej vyššie uvedenú príjmovú hranicu, ktorá podla § 139c ods. 2 zákona o sociálnom poistení predstavuje rozdiel medzi mesačným príjmom (resp. priemerným mesačným príjmom) a zákonom ustanovenou „oslobodzovacou“ príjmovou hranicou. V prípade nepravidelne odmeňovaného dohodára (príp. aj jednorazovo odmeňovaného), ktorému by bol vyplatený príjem po skončení trvania dohody, sa poistné určí z „priemerného“ mesačného príjmu (ak presiahne vyššie uvedenú hranicu), ktorý je podl’a $\S 139$ b ods. 1 zákona o sociálnom poistení výsledkom „rozpočítania“ dodatočne vyplateného príjmu na jednotlivé mesiace trvania danej dohody o prácach vykonávaných mimo pracovného pomeru $\mathrm{v}$ danom kalendárnom roku.

K vol'be práva určit' prostredníctvom čestného vyhlásenia dohodu, na základe ktorej nebude mat'študent / poberatel' dôchodkovej dávky postavenie zamestnanca na účely dôchodkového poistenia uvádzame, že $\mathrm{v}$ aplikačnej praxi nastali viaceré situácie uplatnenia si vol'by práva súčasne u viacerých zamestnávatel'ov, ktorí nemali možnost' verifikovat' údaje uvedené $\mathrm{v}$ čestnom vyhlásení podanom študentom ${ }^{17}$ a ktorých po zistení tejto skutočnosti Sociálna poist’ovňa sankcionovala jednak za neprihlásenie študenta

15 Podl'a $§ 231$ ods. 1 písm. b) bodu č. 3 zákona o sociálnom poistení je zamestnávatel’ povinný prihlásit’ do príslušného registra zamestnanca v právnom vzt’ahu na základe ním určenej dohody, ktorý mu zakladá právo na nepravidelný príjem, na dôchodkové poistenie najneskôr do 8. dňa druhého mesiaca nasledujúceho po mesiaci, v ktorom právny vzt’ah zanikol alebo ak bol príjem vyplatený až po uplynutí tejto lehoty, tak do 8. dňa mesiaca nasledujúceho po mesiaci, v ktorom bol tento príjem vyplatený (súčasne je to aj deň splatnosti poistného) za predpokladu, že priemerný mesačný príjem z tejto dohody presiahol sumu $200 €$.

16 Percentuálne sadzby odvodovej povinnosti na dôchodkové poistenie zamestnávatel'a sú 14 \% na starobné poistenie, $3 \%$ na invalidné poistenie, $4,75 \%$ do rezervného fondu solidarity. Súčasne zamestnávatel' z titulu poistenca úrazového a garančného poistenia platí, ale pozor z celej sumy odmeny študenta, poistné na úrazové poistenie $0,8 \%$ a poistné na garančné poistenie $0,25 \%$. Z uvedeného vyplýva, že zamestnávatel' platí poistné na oba zmienené podsystémy sociálneho poistenie z titulu každej uzatvorenej dohody o prácach vykonávaných mimo pracovného pomeru.

17 Verifikácia údajov uvedených v čestnom vyhlásení je možná iba u nositel’a poistenia, ktorým je Sociálna poist'ovňa a ktorá je ako jediná zo zákona povinná vytvárat' a viest' registre späté s výkonom sociálneho poistenia (osobitne v danom prípade register poistencov a sporitel'ov starobného dôchodkového sporenia). $\mathrm{V}$ danom rozsudku súd záverom konštatuje ,... žalobca ako zamestnávatel nemá prístup do registra žalovaného, v ktorom sú evidované uplatnené výnimky v zmysle zákona o sociálnom poisteni a ani systém žalovaného pri prihlasovani zamestnancov zamestnávatel’mi neupozorní na duplicitné prihlásenie študenta, žalobca nemal inú možnost' ako sa spoliehat' na čestnost' pribratej účastníčky spočívajúcu v pravdivosti jej oznámenia a čestného vyhlásenia o neuplatňovaní si výnimky u iného zamestnávatel'a." 
ako zamestnanca na účely dôchodkového poistenia a jednak hrozilo sankcionovanie pre neplnenie odvodovej povinnosti na dôchodkové poistenie vrátane predpísania penále. Podl'a rozsudku Krajského súdu Bratislava sp. zn. 2S/150/2015 zo dňa 3. februára $2016^{18}$ striktná a formalistická a až mechanická aplikácia zákona o sociálnom poistení Sociálnou poist’ovňou (žalovanou) vedie k nespravodlivému výsledku a nerešpektuje princípy materiálneho právneho štátu (a ktorá vo výsledku zakladá prílišnú tvrdost' zákona voči adresátovi), čo znamená, že „Súdu prislúcha, aby sa zaoberal otázkou, či mechanická a formalistická aplikácia zákona bez ohl'adu na zmysel a účel záujmu chráneného právnou normou, nemôže priniest' absurdné následky a v prípade, že tomu tak je, aby takúto interpretáciu zákona odmietol a zvolil výklad v duchu zákona“. V závere rozsudku krajský súd uvádza, že „Jediným, kto porušil zákon o sociálnom poistení a nepostupoval v súlade s ním, bola pribratá účastnićka, ktorá uviedla žalobcu do omylu a zneužila inštitút odvodového zvýhodnenia, [...] Je neprípustné, aby negatívne dôsledky jej nečestného konania znášal žalobca, ktorému zákon na jednej strane neposkytuje žiadny prostriedok, prostredníctvom ktorého by mohol predist' vzniku takejto situácie, na druhej strane mu za neodvedenie poistného na sociálne poistenie hrozi penále aj napriek tomu, že konal v dobrej viere v pravdivost’ oznámenia a čestného vyhlásenia účastnícky."

D̆alej vo vzt’ahu k poistnej kategórii zamestnanca uvádzame, že zahŕňa vo svojom pojmovom vymedzení aj fyzickú osobu vykonávajúcu zárobkovú činnost' na základe dohôd o prácach vykonávaných mimo pracovného pomeru bez ohl'adu na vyššie uvedené podmienky, ale iba na účely systému úrazového poistenia a garančného poistenia, ktorého poistencom je zamestnávatel'. Uvedená subsumpcia pod poistnú kategóriu zamestnanca na účely úrazového a garančného poistenia je dôsledkom naplnenia princípu rovnosti a ochrannej funkcie sociálneho zabezpečenia, nakol'ko sa týmto definičným vymedzením priznáva a zabezpečuje rovnaký prístup $\mathrm{k}$ dávkam garančného a úrazového poistenia aj fyzickým osobám vykonávajúcim zárobkovú činnost' na základe dohôd o prácach vykonávaných mimo pracovného pomeru vrátane ich rodinných príslušníkov pre prípad smrtel'ného pracovného úrazu alebo choroby z povolania.

V systéme (verejného) zdravotného poistenia je v dôsledku zavedenia zúčtovacieho mechanizmu preddavkov na zdravotné poistenie situácia postavenia fyzických osôb vykonávajúcich činnost' na základe dohôd o prácach vykonávaných mimo pracovného pomeru jednoduchšia a prehl'adnejšia. Zákonodarca vyššie dve uvádzané statusové skupiny „dohodárov“ vylúčil z aktívnej (príspevkovej) participácie na verejnom zdravotnom poistení bez ohl'adu na výšku príjmu a počtu uzatvorených a realizovaných dohôd o prácach vykonávaných mimo pracovného pomeru. Podla § 11 ods. 3 v nadväznosti na $\S 10 \mathrm{~b}$ ods. 1 písm. a) zákona o zdravotnom poistení sa za zamestnanca nepovažuje fyzická osoba vykonávajúca zárobkovú činnost' v právnom vztahu, ktorý jej zakladá právo na príjem daňovo klasifikovaný ako príjem:

1. z dohôd o brigádnickej práci študentov (na rozdiel od systému sociálneho poistenia sa neaplikuje žiadna príjmová hranica),

2. z dohôd o vykonaní práce a dohôd o pracovnej činnosti dvoch relatívne samostatných skupín, a to poberatel'ov starobného dôchodku, predčasného starobného dô-

18 Rovnako aj v prípade rozsudku Krajského súdu Bratislava sp. zn. 6S/165/2015 zo dňa 5. októbra 2017. 
chodku alebo invalidného dôchodku a poberatel'ov výsluhového dôchodku (ak dovŕšili dôchodkový vek) alebo invalidného výsluhového dôchodku.

\subsection{ARGUMENTY V NEPROSPECH ODVODOVEJ PARTICIPÁCIE OSÔB VYKONÁVAJÚCICH ČINNOSŤ NA ZÁKLADE DOHODY O PRÁCACH VYKONÁVANÝCH MIMO PRACOVNÉHO POMERU}

Zavedenie obligatórnej participácie skupiny osôb vykonávajúcich činnost' na základe dohody o vykonaní práce a dohody o pracovnej činnosti s dojednaným pravidelným príjmom z tejto činnosti (s výnimkou poberatel’ov dôchodkových dávok) na nemocenskom poistení a poistení v nezamestnanosti je vzhl'adom na charakter krátkodobosti poskytovania dávok z týchto poistných systémov značne sporný až neúčelný vzhl'adom na ich pracovnoprávne vymedzenie (najmä náhodilost', krátkodobost' a výnimočnost' ich aplikovania zo strany zamestnávatel'a).

Neúčelnost' tohto prístupu identifikujeme jednak v medzinárodnoprávnom zakotvení nevyhnutnosti poskytnutia sociálnoprávnej ochrany pri vzniku nepriaznivých sociálnych udalostí, ktoré môžu nastat' u relevantných skupín ekonomicky činného obyvatel'stva $\mathrm{v}$ intenciách dohovorov Medzinárodnej organizácie práce a jednak vo funkcii dávky poskytovanej osobe vykonávajúcej činnost’ na základe dohody o vykonaní práce a dohody o pracovnej činnosti, štandardne $\mathrm{v}$ iných prípadoch kryje stratu príjmu každý jednotlivý deň trvania sociálnej udalosti, zatial' čo u uvedených osôb kryje stratu príjmu ako následku príslušnej udalosti iba po určité dni, resp. hodiny, počas ktorých by inak táto osoba vykonávala zárobkovú činnost'. Súčasne príležitostný a krátkodobý charakter výkonu zárobkovej činnosti na základe dohody o vykonaní práce a dohody o pracovnej činnosti st’ažuje fyzickým osobám splnenie požiadaviek obsiahnutých v dávkových schémach na priznanie príslušných dávok (ako je napr. materské, dávka $\mathrm{v}$ nezamestnanosti vo vzt’ahu $\mathrm{k}$ splneniu tzv. čakacej podmienky vyžadujúcej nemocenské poistenie $\mathrm{v}$ rozsahu min. 270 dní $\mathrm{v}$ posledných dvoch rokoch alebo dva roky poistenia v nezamestnanosti v posledných štyroch rokov), a to najmä ak fyzická osoba vykonáva sporadicky iba činnost’ na základe uvedených dohôd. V prípade zamestnancov vykonávajúcich prácu $\mathrm{v}$ pracovnom pomere, ktorí príležitostne vykonávajú činnost' na základe uvedených dohôd nenachádzame žiadny dôvod „,sociálno-ochranného“ charakteru, aby výkon činnosti na základe jednej z týchto dohôd zakladal povinnú participáciu na nemocenskom poistení, dôchodkovom poistení a poistení v nezamestnanosti. Ak fyzickej osobe vykonávajúcej zárobkovú činnost' na základe dohody o vykonaní práce alebo dohody o pracovnej činnosti s dojednaným pravidelným mesačným príjmom bude priznaná napríklad náhrada príjmu pri dočasnej pracovnej neschopnosti alebo nemocenská dávka, tak jej suma bude značne nízka ( $v$ dôsledku nizkych vymeriavacích základov na platenie poistného alebo aj $v$ dôsledku aplikovania pravdepodobného denného vymeriavacieho základu v situácii uvedenej $v \$ 57$ ods. 1 písm. b) zákona o sociálnom poistení alebo § 8 ods. 4 alebo § 8 ods. 6 zákona č. $462 / 2003$ Z. z. o náhrade príjmu pri dočasnej pracovnej neschopnosti) v porovnaní s dávkami rovnakého druhu priznanými zamestnancovi vykonávajúcom činnost' v pracovnom pomere na ustanovený týždenný pracovný čas pri jeho mesačnom odmeňovaní na úrovni minimálnej mesačnej mzdy 
(v roku 2018 je to $480 €$; v roku 2019 bude $520 €$ ) alebo minimálnej mzdy za odpracovanú hodinu (v roku 2018 je 2,759 €; v roku 2019 bude 2,989 €), nakol'ko dojednaný rozsah pracovnej činnosti na základe uvedených dohôd (aj po zohl'adnení minimálnej mzdovej požiadavky na odmeňovanie ,dohodára “ podl’a § 223 ods. 2 v nadväznosti na § 119 ods. 1 Zákonnika práce) je podstatne nižší najmä pri dohode o pracovnej činnosti v porovnaní so zamestnancom vykonávajúcom činnost' v pracovnom pomere.

Iný je však pohl'ad na situáciu skončenia dohody o vykonaní práce alebo dohody o pracovnej činnosti, ktorá fyzickej osobe zakladala povinnú participáciu na nemocenskom poistení v spojení s plynutím tzv. ochrannej lehoty v rozsahu 7 kalendárnych dní po skončení nemocenského poistenia na účely potenciálneho vzniku nároku na nemocenské dávky (nemocenské a ošetrovné). Takto naznačená situácia môže zakladat' zneužitie systému nemocenského poistenia a jeho dávkových vzt’ahov. Aj v dôsledku takéhoto potenciálneho scenára zákonodarca sprísnil podmienky na určenie obdobia ako rozhodujúceho obdobia na výmeru nemocenských dávok práve na strane poistnej kategórie zamestnanca. Je to najmä požiadavka nepretržitosti trvania poistného vzt'ahu na nemocenskom poistení a zaplatenia poistného v minimálnom rozsahu 90 dní pred vznikom sociálnej udalosti a pre prípad jej nesplnenia určenie nemocenskej dávky iba zo sumy odmeny poberanej z danej dohody o prácach vykonávaných mimo pracovného pomeru za predpokladu, ak je suma odmeny nižšia ako minimálny vymeriavací základ, z ktorého sa inak určuje suma nemocenskej dávky poskytovaná v porovnatel'nej situáci zamestnancovi v pracovnom pomere alebo obdobnom pracovnom vzt'ahu.

Pokial' ide o povinnú participáciu fyzickej osoby výlučne na dôchodkovom poistení, ktorá je postavení zamestnanca na základe pracovného pomeru a súčasne aj na základe jednej z dohôd o prácach vykonávaných mimo pracovného pomeru, tak jej opodstatnenost' nevylučujeme, nakol'ko takáto fyzická osoba si môže zvýšit' kvalitu budúcich dôchodkových práv. Uvedené by bolo možné aplikovat' aj vo vzt'ahu k výlučnému dôchodkovému poisteniu fyzických osôb vykonávajúcich činnost' na základe dohody o vykonaní práce a dohody o pracovnej činnosti za predpokladu, že tieto osoby dosahujú z týchto dohôd taký príjem, ktorý je v určitom predvídanom čase (v dôchodkovom systéme je to obdobie jedného roka, t. j. 365 dní poistenia) spôsobilý podporit' kvalitu budúceho nadobúdaného dôchodkového práva primeraného prostredníctvom získania kvalitatívne vyššieho „dôchodkového“ výpočtového parametra tzv. osobného mzdového bodu $(\mathrm{OMB})^{19}$. Práve z definičného vymedzenia OMB-u plynie opodstatnenost' obligatórnej participácie na dôchodkovom poistení u tých fyzických osôb, ktoré na základe dlhodobejšieho výkonu činnosti na základe dohody o vykonaní práce alebo dohody o pracovnej činnosti dosahujú v priemernom mesačnom vyjadrení príjem na úrovni priemernej mesačnej mzdy v hospodárstve SR, od ktorej sa nepriamo odvodzuje aj primeranost' hmotného zabezpečenia $v$ starobe a v aplikačnej rovine aj výmera základnej dôchodkovej dávky. Takým príjmom ale nie je príjem fyzickej osoby vykonávajúcej činnost' na základe dohody o vykonaní práce alebo dohody o pracovnej činnosti, a ani dohody o brigádnickej práci študentov, ktorý je nižší ako suma minimálneho vy-

19 Dopíňame, že osobný mzdový bod vyjadruje pomer medzi osobným vymeriavacím základom (t. j. ročným príjmom z ktorého platil poistenec poistné na dôchodkové poistenie) a sumou všeobecného vymeriavacieho základu (t. j. 12 - násobku priemernej mesačnej mzdy v hospodárstve SR) za príslušný kalendárny rok. 
meriavacieho základu zamestnanca v pracovnom pomere odmeňovaného na minimálnej úrovni (minimálnou mesačnou mzdou alebo minimálnou mzdou za odpracovanú hodi$n u)$ za rozhodujúce obdobie, ktorým je (predchádzajúci) kalendárny mesiac.

Nepravidelný príjem ,dohodára“ (vrátane statusových skupín poberatel’ov dôchodkových dávok a žiakov a študentov), ktorý nie je v rovnakom čase aj v pracovnom pomere, a ktorý je nižší ako suma minimálneho vymeriavacieho základu zamestnanca v pracovnom pomere nepredstavuje pre „dohodára“ fakticky žiadnu kvalitu v získavaní budúcich dôchodkových práv.

Na základe doteraz uvedeného sa natíska čiastkový hodnotiaci záver je zjavné, že zákonodarca pri snahe o čiastkové zapojenie fyzických osôb vykonávajúcich činnost' na základe dohôd o prácach vykonávaných mimo pracovného pomeru do systémov sociálnej ochrany okrem poistno-akumulačných snáh s ciel'om zaistenia ich finančnej udržatel’nosti bol nútený preniest' ich osobitný charakter ako atypických pracovnoprávnych vztahov aj do právnej úpravy predovšetkým systému sociálneho poistenia.

Z porovnania sociálnoprávneho postavenia fyzických osôb vykonávajúcich činnost' na základe dohôd o prácach vykonávaných mimo pracovného pomeru oproti skupine zamestnancov vykonávajúcich činnost' na základe pracovného pomeru vyvodzujeme záver, že fyzické osoby vykonávajúce činnost' na základe dohôd o prácach vykonávaných mimo pracovného pomeru predstavujú skupinu fyzických osôb (resp. poistencov) s nižšou úrovňou reálnej sociálnej ochrany, teda ide o skupinu poistencov, ktorí prevažne do systému sociálneho poistenia (osobitne dôchodkového poistenia) len odvádzajú poistné.

Z generálneho pohl'adu sme názoru, že fyzické osoby vykonávajúce činnost' na základe dohôd o prácach vykonávaných mimo pracovného pomeru majú podliehat' obligatórnej participácii na systémoch sociálnej ochrany (menovite na nemocenskom poistení, dôchodkovom poistení a verejnom zdravotnom poistení), ale za inak kvalitatívne nastavených podmienok, ktoré efektívne vyselektujú krátkodobo trvajúce neret’azené dohody o prácach vykonávaných mimo pracovného pomeru s dosahovaným príjmom, ktorý je z pohl'adu efektívnej sociálno-poistnej ochrany marginálny a až nepodstatný. Naznačené je možné dosiahnut' bud' prostredníctvom zavedenia mechanizmu ročného zúčtovania pri definovaní príjmovej hranice z titulu uskutočnených dohôd ${ }^{20}$, pri prekročení ktorej vznikne fyzickej osobe výlučne povinná participácia na dôchodkovom poistení alebo prostredníctvom kvalitatívnych požiadaviek spojených so vznikom povinnej participácie na nemocenskom poistení, dôchodkovom poistení a verejnom zdravotnom poistení (a to predovšetkým definovaním požiadavky vymedzujúcej pojem „ret’azenia“ dohôd, požiadavky na dobu trvania konkrétnej dohody a napokon výšky odmeny (resp. príjmu) plynúceho z konkrétnej dohody).

20 Dňa 23. októbra 2018 prijal slovenský zákonodarca zákon, ktorým sa s účinnost’ou od roku 2021 zavádza platenie preddavkov poistného na sociálne poistenie s ich následným ročným zúčtovaním v roku 2022. Schválené znenie zákona dostupné online na: <https://www.nrsr.sk/web/Default.aspx?sid=zakony /zakon\&MasterID=6832>, navštívené dňa 25. októbra 2018. 


\section{DÔSLEDKY VÝKONU ZÁVISLEJ PRÁCE NA VZNIK NÁROKU NA VÝPLATU DÁVKY}

Pojmové vymedzenie poistnej kategórie zamestnanca a jej previazanie na zdanitel’né príjmy zo závislej činnosti plynúce zo širokého spektra právnych vzt’ahov malo a má svoj dosah aj na poberatel'ov dôchodkových dávok vykonávajúcich zárobkovú činnost' po vzniku nároku na dôchodkovú dávku, a osobitne poberatel'ov predčasných starobných dôchodkov. Od roku 2011 zákonodarca pristúpil k zavedeniu pravidla o zániku nároku na výplatu predčasného starobného dôchodku jeho poberatel'ovi po obdobie, v ktorom vykonával zárobkovú činnost' zakladajúcu mu dôchodkové poistenie, čo od roku 2011 zakladala spravidla každá zárobková činnost' uskutočňovaná v legálnom právnom vzt’ahu, odhliadnuc od obchodnoprávnych vzt’ahov. Nezriedka sa vyskytujú situácie malých (až nepatrných) príjmov s dohodnutou nepravidelnost'ou ich vyplácania, ktoré spôsobujú zánik nároku na výplatu predčasného starobného dôchodku jeho poberatel’ovi, ktorý je iba v menšom rozsahu zárobkovo činný. Súčasne tento malý príjem nepostačuje takémuto dôchodcovi hradit' si životné potreby. Uvedené pravidlo bolo vo vzt'ahu $\mathrm{k}$ dosahovanému nepatrnému a nepravidelnému príjmu zo závislej činnosti a aj v kontexte ochrany pasívneho volebného práva (stažovatel'a, ktorý poberal odmenu za výkon poslanca v obecnom zastupitel'stve v sume 32,79€ za jedno zasadnutie zastupitel'stva určenú $v$ Zásadách odmeňovania poslancov) podrobené ústavnému prieskumu, pričom Ústavný súd SR nezistil arbitrárnost' a svojvôlu v odôvodnení rozsudku Najvyššieho sudu SR, ktorý by zasiahol do st’ažovatel'ovho základného práva na spravodlivý súdny proces, čím potvrdil rozsudok Najvyššieho súdu SR ${ }^{21}$. Najvyšší súd SR v danej veci (sp. zn. 10So/54/2013 zo dřa 28. mája 2014) konštatoval, že poslanec obecného zastupitel'stva s priznaným predčasným starobným dôchodkom poberajúci nepravidelnú odmenu za výkon tohto mandátu, i napriek jeho vyhláseniu o bezodplatnom výkone mandátu poslanca, sa považuje za zamestnanca s právom na nepravidelný príjem zo závislej činnosti, ktorý mu zakladá povinné dôchodkové poistenie po obdobie výkonu mandátu poslanca. Následne mu podl’a $§ 67$ ods. 4 a 5 zákona o sociálnom poistení po obdobie povinného dôchodkového poistenia zaniká nárok na výplatu predčasného starobného dôchodku. Obdobný skutkový stav bol prejedávaný na krajských súdoch, ale pre pochybnosti o existencii vyplácania odmien a následného vzniku povinného dôchodkového poistenia (žalobcu) súdy dané veci vrátili odporkyni (Sociálnej poist’ovni) na d’alšie konanie, v ktorom má úplne a presne zistit' skutočný stav veci²2.

Iným prípadom, ktorého spornost' vychádza z nejednoznačne legálne vyjadreného zámeru zákonodarcu, je súbeh výkonu zárobkovej činnosti (spravidla závislej činnosti) s právom na pravidelný mesačný príjem zakladajúci povinné nemocenské poistenie a nároku na výplatu materského.

Aktuálny výkladový prístup Sociálnej poistovne $\mathrm{k}$ tejto problematike uvádza vo svojom zverejnenom stanovisku, z ktorého vyplýva, že „nárok na výplatu materského zamestnankyña stratí, ak by mala prijem z toho istého pracovnoprávneho vztahu, z kto-

21 Pozri uznesenie Ústavného súdu SR II. ÚS 888/2014 zo dňa 11. decembra 2014.

22 Rozsudok Krajského súdu Banská Bystrica sp. zn. 20Sd/380/2014 zo dňa 22. júla 2015 a rozsudok Krajského súdu Prešov sp. zn. 5Sd/73/2015 zo dňa 28. júla 2016. 
rého jej vznikol nárok na materské“ 23 . Súčasne Sociálna poist'ovňa dodáva, že „Ak sa zamestná na dohodu, ak počas poberania dávky materské uzatvorí iný pracovnoprávny vztah u iného alebo aj pôvodného zamestnávatel'a, výplatu dávky materské jej táto skutočnost' neohrozí. Materské neohrozí ani prijem od jej zamestnávatel'a, ktorý sa viaže na obdobie pred nástupom na materskú."“

$\mathrm{V}$ d’alšom zverejnenom stanovisku Sociálna poist'ovňa len opakuje už uvedené a dodáva „Ak nejde o zamestnankyn̆u, ale o povinne poistenú samostatne zárobkovo činnú osobu alebo o dobrovol'ne nemocensky poistenú osobu, Sociálna poistovña podmienku absencie príjmu neskúma, u týchto skupín osôb nie je totiž absencia príjmu podmienkou priznania nároku na materskéc ${ }^{\text {'24. }}$.

Tento prístup Sociálnej poist'ovne je v priamom rozpore s viacerými znakmi nemocenských dávok a so všeobecnou požiadavkou na priznanie nemocenských dávok. Podl’a $\S 30$ písm. b) zákona o sociálnom poistení nárok na nemocenskú dávku (aj materské) vzniká, ak zamestnanec nemá príjem, ktorý sa považuje za vymeriavací základ na platenie poistného (na nemocenské poistenie) s výnimkou príjmu, ktorý sa poskytuje z iného dôvodu než za vykonanú prácu, a to za obdobie trvania dôvodu na poskytnutie materského.

Uvedené zákonné ustanovenie jasne vylučuje súbeh dosahovania (pravidelného) zdanitel'ného príjmu zo závislej činnosti zamestnankyne a nároku na výplatu materského. Účelom poskytovania nemocenských dávok pokrývajúcich sociálne udalosti kryté systémom nemocenského poistenia je čiastočne zmiernit' stratu príjmu v dôsledku negatívneho pôsobenia danej sociálnej udalosti na socio-ekonomické postavenie chránenej osoby ${ }^{25}$, ktorou je $\mathrm{v}$ tomto prípade tehotná poistenkyňa nemocenského poistenia a matka do konca 9 mesiaca po pôrode. Prístupom Sociálnej poist’ovne je tento účel materského značne spochybnený.

Na podporu nášho postoja podporne poukazujeme aj na jasne realizovaný zámer zákonodarcu zvyšovat' výmeru materského na úroveň „čistého“ príjmu poistenkyne, ktorý dosahovala pred vznikom nároku na materské, t. j. dávková výmera materského sa od mája 2017 zvýšila zo $65 \%$ na $75 \%$ denného vymeriavacieho základu, ktorý zjednodušene predstavuje podiel súčtu príjmov, z ktorých poistenkyňa platila poistné $\mathrm{v}$ určitom rozhodujúcom období a počtu dní tohto obdobia, za ktoré mala povinnost' platit' poistné (na nemocenské poistenie).

Ďalším argumentom je právno-teoretický poznatok o rovnakom prístupe k nemocenským dávkam z hladiska posudzovania podmienok ich priznania a výplaty (resp. realizácie ich dávkových schém) na základe rovnakých požiadaviek a pravidiel za pred-

$23<\mathrm{http}: / /$ www.socpoist.sk/aktuality-prijmy-pocas-materskej-nemusia-ohrozit-poberanie-tejto-davky $-/ 54926 c>$, navštívené dňa 10 . októbra 2018.

24 Rovnaké stanovisko Sociálnej poistovne $\mathrm{k}$ tejto problematike je zverejnené na: $<$ http://www.socpoist . sk $/ 31 / 361$ s?prm $2=60657 \&$ sword $=\&$ insurance_kind $=209 \&$ target_group $=0 \&$ life_sit $=0 \&$ kriterium $=$ all\& page $=2>$, zo dňa 11. októbra 2018 .

25 Tento účel nemocenských dávok sa najzretel'nejšie prejavuje v ich limitovanej percentuálnej výmere z denného vymeriavacieho základu, alebo v českej právnej úprave zmenou denného vymeriavacieho základu prostredníctvom nastavenia redukčných hraníc. Pozri TRÖSTER, P. a kol. Právo sociálního zabezpečení. 6. preprac. vydanie. C. H. Beck, Praha 2013. s. 116. ISBN 987-80-7400-473-5. Pozri MATLÁK, J. a kol. Právo sociálneho zabezpečenia. 2. vyd. Plzeň: Aleš Čeněk, 2012. S. 119. ISBN 978-80-7380-403-9. 
pokladu ich rovnakého alebo podobného účelu. Argumentom a contrario z uvedeného právno-teoretického poznatku a jeho analógiou založenou na uvedenom stanovisku Sociálnej poist'ovne by vo vzt’ahu k poskytovaniu napríklad nemocenského vyplynulo, že dočasne práceneschopný poistenec (zamestnanec) môže vykonávat' zárobkovú činnost' mimo pracovnoprávneho vzt’ahu, z ktorého realizácie bol zákonným spôsobom ospravedlnený po obdobie trvania dočasnej pracovnej neschopnosti. Teda v konečnom dôsledku by $\mathrm{v}$ takto hypotetickej situácii neporušoval výkonom zárobkovej činnosti lekárom nariadený liečebný režim a následne by mu v dôsledku zistenia porušenia liečebného režimu nezanikol nárok na výplatu nemocenského po obdobie najviac 30 dní trvania dočasnej pracovnej neschopnosti.

Ďalej je potrebné poukázat' aj na skutočnost', že ak žena poberajúca materské začne vykonávat' zárobkovú činnost', čo aj s právom na nepravidelný príjem zo závislej činnosti v pracovnoprávnom vzt’ahu (čo jej založí povinné dôchodkové poistenie), tak stráca postavenie poistenca štátu na účely dôchodkového poistenia, t. j. štát za ňu neplatí poistné na dôchodkové poistenie počas poberania materského (§ 128 ods. $5 \mathrm{v}$ spojitosti $\mathrm{s} 15$ ods. 1 písm. c) zákona o sociálnom poistení). Ak by z takejto zárobkovej činnosti poberala príjem zo závislej činnosti nižší ako je polovica priemernej mesačnej mzdy v hospodárstve SR, tak by jej sociálna ochrana bola nižšia než akú poskytuje štát svojim poistencom na účely získavania ich budúcich dôchodkových práv.

Pri hlbšej systémovej analýze tejto problematiky nachádzame ešte jeden argument, ktorý o nedostatočnom legislatívnom vyjadrení dávkovej schémy materského a prípadnej systémovej chybe v prepojení medzi systémom nemocenského poistenia a systémom štátnych sociálnych príspevkov určených na podporu starostlivosti a výchovy diet'at’a.

Dávková schéma materského a súčasne aj nárok na výplatu materského vyžadujú preukázanie podmienky starostlivosti o narodené diet’a, pričom úroveň tejto starostlivosti zákonodarca bližšie nedefinuje, či už na úroveň riadnej starostlivosti alebo osobnej a celodennej starostlivosti. Použitím analógie legis pri vymedzení úrovne starostlivosti o novorodenca je možné aplikovat' úroveň riadnej starostlivosti u jednej zo skupín poistencov štátu na účely dôchodkového poistenia, ktorú zákonodarca podla § 15 ods. 1 písm. c) zákona o sociálnom poistení vymedzuje ako ekonomicky neaktívnu fyzickú osobu s trvalým pobytom na území SR, ktorá sa riadne stará o diet’a do 6 rokov veku. Obsahové vymedzenie riadnej starostlivosti u tejto skupiny poistencov štátu starajúcich sa o diet’a zákonodarca reguluje legislatívno-technickým odkazom na právnu úpravu poskytovania rodičovského príspevku. Ustanovenie $\S 3$ ods. 3 a 4 zákona č. 571/2009 Z. z. o rodičovskom príspevku okrem obsahového vymedzenia riadnej starostlivosti o diet’a vyjadruje vzt'ah oprávnenej osoby $\mathrm{k}$ zaist'ovaniu riadnej starostlivosti o diet'a, a to v osobnej forme alebo v náhradnej forme prostredníctvom plnoletej fyzickej osoby alebo právnickej osoby.

Z uvedenej snahy o prepojenie systému nemocenského poistenia a systému štátnych sociálnych príspevkov na podporu starostlivosti a výchovy diet’ata, kde je premost’ovacím prvkom krytie rovnakej sociálnej udalosti, je zjavný systémový nedostatok založený iným účelom materského (nemocenskej dávky) a stanovenej kvalitatívnej úrovne starostlivosti o diet'a v období od pôrodu až do 3 rokov veku, resp. 6 rokov veku diet’at'a, ak má diet’a dlhodobo nepriaznivý zdravotný stav, na účely poskytovania rodičovského príspevku. 
Preto zastávame názor, že tento zretel’ný systémový „pat“ vyrieši iba legislatívny zásah zákonodarcu, ktorý bud' „potvrdi'“ vyššie uvedený prístup Sociálnej poist’ovne s následkom iného postavenia materského voči ostatným nemocenským dávkam, alebo legislatívne precizuje úroveň starostlivosti na účely poskytovania materského, a tak ju definične oddelí v rámci totožnej sociálnej udalosti voči nadväzujúcemu poskytovaniu rodičovského príspevku v rámci tej istej sociálnej udalosti.

Napokon k uvedenej nesystémovosti medzi systémom nemocenského poistenia a štátnych sociálnych príspevkov dodávame, že tá vznikla zmenou prístupu zákonodarcu k situácii výkonu zárobkovej činnosti oprávnenou osobou, ktorej vznikol nárok na výplatu rodičovského príspevku, a to zákonom č. 571/2009 Z. z. účinným od 1. januára 2010. Právna úprava účinná do konca roka 2009 totiž zakotvovala v definičnom vymedzení riadnej starostlivosti o diet’a ako jednej z požiadaviek na vznik nároku na výplatu rodičovského príspevku osobne (rodičom) poskytovanú starostlivost' diet’at'u v záujme jeho fyzického a psychického vývinu, pričom exemplifikatívnym spôsobom túto úroveň starostlivosti obsahovo vymedzovala.

\section{NÁSLEDKY SUBSUMPCIE KONATELA A SPOLOČNÍKA SPOL. S R.O. POD POISTNÚ KATEGÓRIU ZAMESTNANCA}

V tejto časti analyzujeme špecifiká odvodovej participácie konatel’a (a aj spoločníka) spol. s r.o. vrátane situácie vyplatenia podielu na zisku, pričom odhliadame od d'alšieho vznikajúceho teoreticko-aplikačného problému založeného nálezom Ústavného súdu ČR (sp. zn. I ÚS 190/15 zo dňa 13. septembra 2016) a z neho argumentačne vychádzajúcim rozsudkom Najvyššieho súdu ČR (sp. zn. Cdo 4831/2017) o možnosti člena štatutárneho orgánu obchodnej spoločnosti dojednat' (napr. v managerskej zmluve) podriadenie činností (ktoré nemajú podl'a obchodnoprávnych predpisov kogentnú povahu) pracovnoprávnemu režimu výkonu závislej práce podl’a Zákonníka práce, čo podnietilo diskusiu o tejto problematike aj v slovenských odborných kruhoch ${ }^{26}$. Vzhl'adom na uvedené predstavíme aj situáciu odvodovej participácie konatel'a spol. s r.o., ktorý je súčasne aj v pracovnom pomere, a teda zamestnancom spol. s r.o.

Právna úprava systému sociálneho poistenia účinná od 1. januára 2011, ktorá zaviedla priame prepojenie medzi zárobkovou činnost'ou poistnej kategórie zamestnanca a daňového vymedzenia príjmu zo závislej činnosti spôsobila, že konatelia a spoločníci spoločností s ručením obmedzením sa považujú na účely sociálneho poistenia a verejného zdravotného poistenia za zamestnanca. Táto zmena právnej úpravy spôsobila, že konatel' a spoločník spol. s r.o. majú rôznu úroveň obligatórnej (zákonnej) sociálnej ochrany v poist'ovacom systéme, ktorú dokážu menit' vlastným rozhodovaním sa, ked'že konatel' je v postavení štatutárneho orgánu a súčasne môže byt’ aj spoločníkom spol. s r.o. a d'alej aj v situácii jednoosobovej spol. s r.o..

26 Pozri k tomu BARANCOVÁ, H. Zamestnanec, štatutár a spoločník v pracovnom práve. Praha: Leges, 2018. s. 84-87. ISBN 978-80-7502-300-1. a za oblast' obchodného práva CSACH, K. Súbeh výkonu funkcie člena štatutárneho orgánu a pracovného pomeru - revolúcia na obzore? (k nálezu Ústavného súdu ČR z 13. septembra 2016). In: Súkromné právo. ISSN 1339-8652, 2017, roč. 3, č. 1, s. 2-8. 
V základnej situácii, ak konatel' spol. s r.o. (zároveň môže a aj nemusí byt' spoločníkom) nepoberá odmenu za výkon tejto funkcie, tak neparticipuje na systémoch sociálneho poistenia. V prípade systému zdravotného poistenia vzhl'adom na jeho osobitnú existenciu trvania poistného vzt’ahu a absolútnu solidaritu vyžadujúcu plnenie odvodovej povinnosti v každom období života poistenca (či priamu alebo suplovanú spravidla štátom) je konatel' v postavení samoplatitel'a poistného na verejné zdravotné poistenie ${ }^{27}$.

Opačnou situáciou a častejšou je poberanie odmeny za výkon funkcie konatel'a. Je potrebné rozlíšit', či má konatel' právo na pravidelnú mesačnú odmenu alebo nie (pri určovani pravidelnosti mesačného zdanitelného prijmu zo závislej činnosti je rozhodujúce zmluvné zakotvenie práva na pravidelný prijem s mesačnou splatnostou, nie jeho zúčtovanie či faktická výplata ${ }^{28}$ ). Ak konatel' pravidelne mesačne poberá odmenu, tak má odvodové zat'aženie rovnaké ako „klasický“ zamestnanec v pracovnom pomere. Ak je nepravidelne odmeňovaný za výkon funkcie konatel'a, tak výlučne obligatórne participuje na dôchodkovom poistení2 ${ }^{29}$, pričom ale spol. s r. o. aj ked' má postavenie zamestnávatel'a, tak neplatí úrazové a garančné poistenie a teda nie je úrazovo a garančne poistená (dôvodom je charakter obchodno-záväzkového vzt'ahu medzi konatel’om a spol. s r.o. nezlučitel'ný s účelom uvedených poistení). Osobitne dodávame, že ak je konatel'ovi s.r.o. vyplatená (nepravidelná) odmena počas kalendárneho roka, tak podl’a §139b ods. 2 zákona o sociálnom poistení sa suma tejto odmeny rozpočíta medzi jednotlivé mesiace trvania tohto poistného vzt’ahu na dôchodkovom poistení v poslednom (aktuálnom) roku až do mesiaca, ktorý predchádza mesiacu výplaty odmeny, a to až do dosiahnutia sumy maximálneho vymeriavacieho základu na platenie poistného ${ }^{30}$. Tento právny stav vytvára možnost’ úniku z plnenia odvodovej povinnosti v situácii vyplatenia vysokej odmeny prevyšujúcej sumu maximálneho vymeriavacieho základu na platenie poistného do systémov sociálneho poistenia v prvý mesiac nasledujúceho kalendárneho roka (a rozhodnút' o ich vyplatení možno aj na konci predchádzajúceho roka). Tento prístup o úniku z plnenia odvodovej povinnosti je taktiež aplikovatelný na vysokopríjmové skupiny zamestnancov ${ }^{31}$.

27 Samoplatitel' poistného na verejné zdravotné poistenie je osobou, ktorá nemá postavenie zamestnanca, ani SZČO a ani poistenca štátu, pričom jej odvodová povinnost' predstavuje $14 \%$ z polovice priemernej mesačnej mzdy v hospodárstve SR platnej pred dvoma rokmi (pre rok 2018 je to suma 63,84€ určená ako 14 \% (912/2)). Polovičná percentuálna sadzba sa vzt’ahuje na platitel’ov poistného so zdravotným postihnutím (či v postavení invalidnej osoby alebo fyzickej osoby s t’ažkým zdravotným postihnutím).

28 Túto interpretáciu podporuje aj stanovisko Sociálnej poist'ovne: „Za zamestnanca v právnom vzt’ahu, ktorý mu zakladá právo na nepravidelný príjem, sa považuje konatel', ak nemá právo na príjem zo závislej činnosti pravidelne za každý kalendárny mesiac, ale napr. jednorazovo raz ročne, raz štvrtročne, raz za dva mesiace. "Dostupné online na: $<$ https://www.socpoist.sk/poradna-pre-eu/1232s?prm2=47630\&sword $=\&$ insurance_kind $=0 \&$ target_group $=0 \&$ life_sit $=0 \&$ kriterium $=$ all\&page $=24 \&$ set_subframe $=$ blind $>$, navštívené dňa 29. septembra 2018.

29 Poistné na dôchodkové poistenie sa skladá z poistného na starobné poistenie (4 \% zo sumy odmeny platí konatel' a $14 \%$ zo sumy odmeny spol. s r.o.), poistného na invalidné poistenie (po $3 \%$ zo sumy odmeny tak konatel' ako aj spol. s r.o.) a poistné do rezervného fondu solidarity (4,75\% iba spol. s r.o.).

30 Schéma definujúca maximálny vymeriavací základ na platenie poistného je 7-násobok priemernej mesačnej mzdy v hospodárstve SR platnej pred dvoma rokmi, čo pre rok 2018 znamená hranicu $6383 €$ a pre rok 2019 hranicu $6678 €$.

31 Uvedená možnost' zákonodarcom tolerovaného úniku z pod „,plnej“ odvodovej povinnosti na účely sociálneho poistenia je už dlhšie predmetom odborných diskusií. Napr. pozri úvod článku dostupného online na: $<$ https://www.iness.sk/sk/rocne-zuctovanie-moze-priniest-nespravodlivost-trend>, navštívené dňa 5. 9. 2018. 
Na účely platenia poistného na zdravotné poistenie z vyplatenej nepravidelnej odmeny konatel'ovi sa odvodová situácia komplikuje. Z vyplatenej odmeny za daný mesiac platí konatel' a aj spol. s r.o. ako zamestnávatel' preddavky na zdravotné poistenie a v mesiacoch, v ktorých nemá konatel' právo na odmenu sa považuje za samoplatitel'a poistného na zdravotné poistenie. Takto zákonodarcom navodený právny stav vytvára priestor pre špekulatívne správanie, ked’že konatel' je kompetenčne spôsobilý navodit' vel'mi nízku sumu odmeny vyplácanú pravidelne, čím „obíde“ zákonodarcom určenú minimálnu sumu preddavku na zdravotné poistenie, ktorú by musel odvádzat' v postavení samoplatitel'a poistného a aj v porovnaní s ,klasickým“ zamestnancom odmeňovaným v pracovnom pomere minimálnou mzdou (v roku 2018 je to mesačná minimálna mzda $480 €$ pre 1 . stupeň náročnosti práce a minimálna hodinová je $2,759 €$ pre 1 . stupeň náročnosti práce; v roku 2019 je mesačná minimálna mzda $520 €$ a minimálna hodinová mzda pre 1. stupeň náročnosti práce $2,989 €$ ). A v konečnom dôsledku má konatel' v takto navodenom stave vyplácania „nízkych odmien“ nárok na rovnakú úroveň (kvalitu) poskytovanej zdravotnej starostlivosti ako iní poistenci, ktorí riadne platia poistné na zdravotné poistenie zo svojich miezd a platov či iných druhov príjmov zo závislej činnosti.

Ked’že v posledne uvedených dvoch situáciách konatel'ovi spol. s r.o. vzniká povinné poistenie v systémoch sociálneho poistenia, tak je potrebné určit' vznik/zánik poistného vzt'ahu u konatel'a s pravidelnou alebo nepravidelnou vyplatenou odmenou, pričom rozhodujúcou skutočnost'ou je deň zápisu vykonávania funkcie do obchodného registra ${ }^{32}$. Uvedený interpretačný prístup potvrdzuje aj stanovisko Sociálnej poist'ovne, podl'a ktorého „Konatel' (a aj spoločník) spol. s r.o. nadobudne postavenie zamestnanca na účely sociálneho poistenia iba v prípade, ak mu vznikne právny vzt’ah konatel'a alebo spoločníka zápisom do obchodného registra, a zároveñ, ak mu určitý úkon (napríklad mandátna zmluva, zmluva o výkone funkcie) zaručuje právo na príjem zo závislej činnosti za prácu konatel'a alebo spoločníka. Pritom nie je rozhodujúce, či spoločník alebo konatel' má odmenu skutočne vyplatenú. Dôležité je, že má právo na tento príjem. ${ }^{33}$.“ Špecificky by sa postupovalo v prípade, ak konatel' vykonáva funkciu bez nároku na odmenu a valné zhromaždenie spoločnosti by prijalo rozhodnutie o priznaní jednorazovej odmeny konatel'ovi. V takom prípade by konatel'ovi vzniklo povinné dôchodkové poistenie zamestnanca prijatím rozhodnutia valného zhromaždenia.

V systéme (verejného) zdravotného poistenia uvedené nie je potrebné skúmat', ked’že poistný vzt'ah vzniká spravidla narodením a končí smrtou, a teda dochádza len k zme-

32 V súvislosti s určovaním vzniku a zániku poistného vzt’ahu (vzt’ahov) v systémoch sociálneho poistenia bolo v určitých kruhoch diskutabilné, či poistný vzt’ah vzniká vznikom právneho vzt’ahu, ktorý zakladá právo na takýto príjem ale až faktickým vyplatením príjmu či vzdaním sa nároku na príjem/odmenu. Pozri rozsudok Krajského súdu Banská Bystrica sp. zn. 20Sd/380/2014 zo dňa 22. júla 2015. V tomto rozsudku sú dôvodí, že ,pre vznik a trvanie postavenia zamestnanca s nepravidelným príjmom na účely dôchodkového poistenia nepostačuje sama o sebe skutočnost', že osoba je v právnom vzt’ahu, ktorý jej zakladá právo na nepravidelný prijem bez ohl'adu na to, že či sa (tohto) práva vzdala alebo nie, ktorá zastáva odporkyňa“. A následne dodáva, že ,podl'a názoru súdu pre splnenie podmienky postavenia zamestnanca, okrem právneho vzt’ahu je potrebné naplnit' aj materiálny obsah tohto vzt’ahu“. Tento ojedinelý judikatórny prístup bol ale odmietnutý rozsudkom Najvyššieho súdu SR sp. zn. 10So/54/2013 z 28. mája 2014 aj uznesením Ústavného súdu SR II. ÚS 888/2014 zo dňa 11. decembra 2014.

33 Dostupné online na: <https://www.socpoist.sk/poradna/326s?prm2=55322\&sword=\&insurance_kind $=260 \&$ target_group=0\&life_>, navštívené dňa 10 . septembra 2018 . 
ne platitel'a poistného, ak napríklad $\mathrm{v}$ predchádzajúcom roku nemal konatel' vyplatenú žiadnu odmenu alebo bol v evidencii uchádzačov o zamestnanie. Uvedené vo vzt'ahu $\mathrm{k}$ vyplatenej odmene obdobne platí aj pre spoločníka spol. s r.o.

Predposlednou skutkovou situáciou je variant, že konatel' (bez ohl'adu či je alebo nie je spoločníkom) s právom na vyplatenie (resp. pravidelné vyplácanie) odmeny nadobudne postavenia zamestnanca z titulu uzatvorenia pracovnoprávneho vzt’ahu. V tejto situácii sa na účely participácie $\mathrm{v}$ systémom sociálneho poistenia posudzuje každý právny vzt’ah regulujúci tak postavenie konatel'a ako aj postavenie zamestnanca samostatne, pričom pravidelnost' odmeny a mzdy bude rozhodujúca na posúdenie rozsahu odvodovej participácie v sociálnom poistení. Vo verejnom zdravotnom poistení má fyzická osoba s vyplácanou odmenou konatel'a spol. s r.o. a s vyplácanou pracovnoprávnou mzdou (odmenou) vždy postavenie zamestnanca bez potreby d'alšieho rozlišovania postavenia.

Napokon uvádzame právne riešenie situácie vyplatenia podielu na zisku (poznamenávame, že dividenda nie je príjmom zo závislej činnosti) konatel’ovi, ktorému je vyplatená (resp. pravidelne vyplácaná) odmena a ktorý je bud’ aj spoločníkom spol. s r.o. alebo ním nie je. Ak konatel' nie je spoločníkom spol. s r.o., tak vyplatený podiel na zisku podlieha podla $§ 138$ ods. 1 zákona o sociálnom poistení odvodovej povinnosti, a to len na účely dôchodkového poistenia za predpokladu, že konatel' má právo len na nepravidelne vyplácanú odmenu; inak aj na účely nemocenského poistenia a poistenia v nezamestnanosti. Ak konatel' vo vyššie uvedenom skutkovom postavení je spoločníkom spol. s r.o., tak vyplatený podiel na zisku nepodlieha odvodovej povinnosti na účely sociálneho poistenia. Ak konatel’ nemá právo na vyplatenie/vyplácanie odmeny a je mu vyplatený podiel na zisku, je právne irelevantné či má postavenie spoločníka a podiel na zisku v absolútnom vyjadrení nepodlieha odvodovej povinnosti na účely sociálneho poistenia. Ak je spoločníkovi spol. s r.o. vyplatený podiel na zisku, tak tento podiel na zisku nezakladá odvodovú povinnost’ na účely sociálneho poistenia. Poznamenávame, že podiel na zisku vyplatený z účtovného roka 2017 nepodlieha odvodovej povinnosti na účely zdravotného poistenia (bližšie $k$ tomu pozri poznámku pod čiarou č. 7).

Dodávame, že ak konatel' spol. s r.o. je aj spoločníkom a poberá odmenu za výkon funkcie konatel'a a aj odmenu spoločníka na základe práva na odmenu (zakotvenú v spoločenskej zmluve), tak každý právny vzt’ah regulujúci jeho postavenie konatel’a a postavenie spoločníka s právom na odmenu sa posudzuje na účely participácie v systémoch sociálneho poistenia samostatne. Vo verejnom zdravotnom poistení má fyzická osoba s vyplácanou odmenou tak pre spoločníka a ako aj konatel'a spol. s r.o. vždy postavenie zamestnanca bez potreby rozlišovania postavenia $\mathrm{v}$ spoločnosti.

Na komplikovanú a obtiažne prehl'adnú právnu úpravu poistno-odvodovej participácie konatela (a aj spoločníka) spol. s r.o. s právom na výplatu nepravidelnej odmeny (príp. podielu na zisku) musela zareagovat' aj právna úprava dávkových vzt’ahov dôchodkového poistenia. Podla $\S 60$ ods. 6 zákona o sociálnom poistení nie je hodnoteným obdobím dôchodkového poistenia na účely výmery dôchodkovej dávky obdobie dôchodkového poistenia zamestnanca, v ktorom nemal vymeriavací základ na platenie poistného. Toto pravidlo reflektujúce na prevalenciu zásluhovosti pri výmere dôchodkových dávok predstavuje v tomto prípade opodstatnené zníženie úrovne sociálnej ochrany, 
ktorú by ale mohol zákonodarca de lege ferenda zmiernit' zakotvením možnosti doplatenia poistného na dôchodkové poistenie s účinkom ex tunc ako tak urobil už v štyroch taxatívne vymedzených prípadoch (uvedených $v$ \$ 142 ods. 3 zákona o sociálnom poisteni).

\section{ZÁVER}

Súčasný pracovnoprávny prístup $\mathrm{k}$ identifikácii znakov závislej práce sa odvíja od pojmových znakov „typického“ zamestnanca (vyvodzovaných z materiálnych okolností jej výkonu), ktoré bez vážnych pochybností určia v spoločenských vzt’ahoch realizujúcich právo na (závislú) prácu také indikátory, ktoré oddelia výkon závislej práce od iných samostatných foriem výkonu práce. Tento prístup sa preberá aj do výstavbových prvkov systémov sociálnej ochrany, a to previazaním účasti (resp. participácie) vo všeobecných systémoch sociálnej ochrany pokrývajúcich podstatnú čast' katalógu sociálnych udalostíi ${ }^{34} \mathrm{~s}$ výkonom najvýznamnejších druhov zárobkovej činnosti ${ }^{35}$, ktorou rozhodne je závislá práca reprezentovaná určitými skupinami zamestnancov selektovanými podla kritéria potreby zaručenia (primeranej) sociálnej ochrany. Tento výstavbový prístup sa vo vztahu k osobnému rozsahu príspevkových systémov sociálnej ochrany SR aplikoval do konca roka 2010 a následne bol nahradený vo vzt’ahu k poistným kategóriám zamestnanca a samostatne zárobkovo činnej osoby prepojením na daňovú klasifikáciu príjmov zo zárobkovej činnosti.

Rozsiahle a možno povedat' až maximalistické zapojenie početných skupín fyzických osôb do príspevkovej (odvodovej) participácie na účely sociálneho poistenia a verejného zdravotného poistenia SR vykonané v období rokov 2011 až 2013 prinieslo, okrem vy̌šsej poistnej akumulácie, nie zanedbatel'né nedostatky, ktoré majú prevažne systémový a vecný charakter vo vzt’ahu k existujúcemu nastaveniu poistných ale aj dávkových vzt’ahov systému sociálneho poistenia.

V jadre príspevku bola analyzovaná pojmová redefinícia poistnej kategórie zamestnanca, ktorá priniesla „pseudo“ sociálnu ochranu (zakrývajúca iba snahu o vyššiu alokáciu poistného) fyzickým osobám vykonávajúcim prácu na základe dohôd o prácach vykonávaných mimo pracovného pomeru v podobe t’ažkopádnosti legislatívnej úpravy a neúčelnosti (čo do výšky dosahovaného príjmu a čo do ich krátkodobosti s výnimkou ich ,retazenia/opakovania "), d’alej systémový nedostatok v prepojení na dávkové vzt’ahy realizujúce výplatu materského a predčasného starobného dôchodku a napokon len obtiažne prehladnú, $v$ určitom aspekte plnenia odvodovej povinnosti verejného

34 Minimálny rozsah katalógu sociálnych udalostí je obsiahnutý v Dohovore MOP č. 102 o minimálnej norme sociálneho zabezpečenia z roku 1952, ktorý bol publikovaný ako Oznámenie Federálneho ministerstva zahraničných vecí č. 461/1991 Zb. a pre ČSFR záväzný od 11. januára 1991 s výnimkou podpory v nezamestnanosti a dávok pri pracovných úrazoch a chorôb z povolania.

35 Tento prezentovaný prístup podporujeme vymedzením okruhu chránených osôb pri jednotlivých sociálnych udalostiach zakotvených v dohovore MOP č. 102 alebo dohovore č. 128 o invalidných, starobných a pozostalostných dávkach z roku 1967, ktorý bol publikovaný ako Oznámenie Federálneho ministerstva zahraničných vecí č. 416/1991 Zb. a pre ČSFR je záväzný od 11. januára 1991 iba v jeho časti III. 
zdravotného poistenia až špekulatívnu, právnu úpravu postavenia konatel’a (a aj spoločníka) spol. s r.o. ako obsahovej súčasti uvedenej poistnej kategórie.

Tieto nedostatky predznačujú nel'ahkú legislatívnu a systémovo-výstavbovú cestu pri zachovaní funkcií príspevkových systémov sociálnej ochrany, ktorá sa už v tomto období očakáva zo strany informačných technológií prostredníctvom ktorých sa začína uskutočňovat' výkon (doterajšej) závislej práce. Už len jedna významná zmena, akou bolo definičné previazanie poistnej kategórie zamestnanca na daňovú klasifikáciu príjmov zo závislej činnosti, dokázala vyvolat' kontroverzie či nedostatky v nastavení a funkciách sociálnopoistovacieho právneho vzt’ahu v podmienkach SR, čo potom možno očakávat' od nastavení vyvolaných novými digitálnymi platformami výkonu zárobkovej činnosti, ktoré okrem iného oslabia aj súčasné bazálne znaky závislej práce. A súčasné nedostatky v systémovom nastavení sociálnopoistovacieho právneho vzt’ahu, v ktorom je subjektom osoba vykonávajúca činnost' na základe dohôd o prácach vykonávaných mimo pracovného pomeru a konatel' spol. s r.o. (najmä ak nemá majetkovú účast' na spoločnosti), pritom nie sú vyvolané fenoménom nových informačných technológií, ale sú výsledkom nedoriešeného vzt’ahu medzi „typickým“ pracovným pomerom (výkonom závislej práce) a výkonom činností, ktoré sú na pomedzí výkonu závislej práce a podnikania (najmä obchodnoprávnych vzt’ahov), a to minimálne v dôsledku vol’nejšieho rozhodovania o niektorých dimenziách výkonu závislej práce. Je preto nevyhnutné pri vysporiadavaní sa s uvedenou reláciou „klasický/typický“ zamestnanec a člen štatutárneho orgánu identifikovat' a zohl'adnit' znaky nových zmiešaných (resp. digitálnych) foriem výkonu práce a vo výsledku zvážit vytvorenie modelu tzv. ekonomicky (resp. hospodársky) závislých osôb, s ktorým by sa spájala určitá (primeraná36) úroveň sociálnoprávnej ochrany týchto osôb. Rozhodne bude predmetom diskusie rozsah a forma participácie v príspevkových systémoch sociálnej ochrany vzhl'adom na v niektorých prípadoch problematické objektivizovanie dosahovaného príjmu vrátane jeho prevažujúcej pravidelnosti (obdobou tohto očakávaného stavu je v súčasnosti činnost' (výkonného) umelca a autora a ich odvodová participácia v sociálnom poistení $v$ postaveni samostatne zárobkovo činnej osoby).

V konečnom dôsledku slovenský zákonodarca prvý výrazný krok k verifikácii hospodárskej závislosti naznačenej novej kategórie „kvázi““ zamestnancov uskutočnil vyššie uvedenou redefiníciou poistnej kategórie zamestnanca spojenou s rovnako extenzívnym vymedzením zamestnávatel’a. Ďalší krok, ktorým je zavedenie modelu ročného zúčtovania v systéme sociálneho poistenia (od roku 2005 sa aplikuje vo verejnom zdravotnom poisteni), pripravil s predpokladanou účinnost'ou od roku 2021. Zastrešenie určitou (primeranou) úrovňou sociálnej ochrany všetkých foriem pracovnoprávnych vzt'ahov (vrátane kategórie zamestnancov platforiem) akcentuje vo svojej preambule a v zásade č. 12 Európsky pilier sociálnych práv ${ }^{37}$ a aj samotná podstata a ciel' návrhu Odporú-

${ }^{36} \mathrm{~K}$ primeranosti sociálnej ochrany pozri aj bod č. 16 návrhu Odporúčania Rady o prístupe k sociálnej ochrane pre pracovníkov a samostatne zárobkovo činné osoby, ked’že obsahuje generálne rámcové kritériá ako je dôstojná životná úroveň, dôstojný život, nadobudnutie vhodnej náhrady za stratu na príjme, ochrana pred prepadom do chudoby.

37 Pilier sociálnych práv bol vyhlásený a podpísaný Európskou komisiou, Európskym parlamentom a Radou EÚ dňa 17. novembra 2017 na Sociálnom summite pre spravodlivé pracovné miesta a rast v Göteborgu. 
čania Rady o prístupe k sociálnej ochrane pre pracovníkov a samostatne zárobkovo činné osoby (COM(2018) 132 final). Oba zmienené dokumenty kladú na národného zákonodarcu náročnú úlohu monitorovat’ súčasnú dosiahnutú úroveň sociálnej ochrany zamestnanca a následne ju v prípade deformácie hospodárskymi (a aj technologickými) trendmi dorovnávat' $\mathrm{v}$ prospech zaistenia primeranej sociálnej ochrany zamestnanca v každom druhu pracovnoprávneho vzt’ahu, čo v prípade miestami prekomplikovanej slovenskej právnej úpravy sociálnej ochrany určitých kategórií zamestnancov bude spojené s väčšími t'ažkost’ami.

doc. JUDr. Miloš Lacko, Ph.D.

Katedra pracovného práva a práva sociálneho zabezpečenia

Právnická fakulta Trnavskej univerzity v Trnave

milos.lacko@gmail.com 